\title{
COLOUR EVOLUTION OF CONVENTIONALLY AND ORGANICALLY CULTIVATED HUNGARIAN RED SPICE PAPRIKA VARIETIES \\ ${ }^{1}$ A. Koncsek, ${ }^{2} Z$ s. H. Horváth, ${ }^{2}$ A. Véha, ${ }^{3}$ H. G. Daood, ${ }^{3}$ L. Helyes \\ ${ }^{1}$ Rubin Spice Paprika Processing Szeged Ltd., 173Szerb str., H-6771 Szeged-Szőreg, Hungary e-mail: labor@rubinpaprika.hu \\ ${ }^{2}$ University of Szeged, Faculty of Engineering, 5-7 Moszkvai, H-6725, Szeged, Hungary \\ ${ }^{3}$ Szent-István Uversity, Faculty of Agricultural and Environmental Sciences, 1. Páter Károly Str., H-2100, Gödöllő, Hungary
}

\begin{abstract}
Colour evolution of conventionally and organically cultivated Szegedi-20, Meteorit, Mihálytelki and Kármin spice paprika varieties was studied in green, break, pale red, deep red and over-ripened maturity stages. As the ripening stages forwarded the organic samples gradually lost their initial extractable colour (ASTA value) gain toward their conventional counterparts. The over-ripened colour levels were satisfactorily high in the conventional (169.9-264.8 ASTA) and in the organic (160.8-210.5 ASTA) paprika varieties as well, although the colour accumulation was 9.062.8 ASTA lower in the organic samples. Significant and perceptible visual colour differences $\left(\Delta \mathrm{E}^{*}{ }_{\mathrm{ab}}\right)$ were found between the organic and conventional crops. The lightness difference $\left(\Delta \mathrm{L}^{*}\right)$ indicated that the organic paprika generally were lighter than the conventional ones. The positive hue difference $\left(\Delta \mathrm{H}^{*}{ }_{\mathrm{ab}}\right)$ showed that the colour of deep red and over-ripened organic Szegedi-20, Mihálytelki and Kármin paprika crops were more yellow compared with the conventional group. The lightness $\left(\mathrm{L}^{*}\right)$ and hue angle $\left(\mathrm{h}_{\mathrm{ab}}^{\circ}\right)$ were found the most suitable instrumental colour parameters to distinguish the ripening stages and the colour characteristics of the samples. The better colour evolution of conventional crops was attributed to the soil characteristics, nutrient supply and chemical plant protection that were specifically designed for the needs of paprika in the conventional farming.
\end{abstract}

Keywords: organic, conventional, spice paprika, colour

\section{INTRODUCTION}

The red spice paprika (Capsicum annuum var. longum L.) is one of the most important traditional agricultural crops of Hungary. Their processed forms such as paprika creams and spice paprika powders (milled dried pods) are widely used products in food industry and in gastronomy.

The deep red colour of spice paprika is due to the high level of carotenoids, which accumulate as a result of de novo (light-independent) biosynthesis during the course of ripening [1].Earlier studies demonstrated that the total carotenoid pigment content in the red spice paprika varied between $4.75-12.10 \mathrm{mg} / \mathrm{g}$ influenced by the variety, weather conditions in the growing season, crop production methods and conditions of processing technologies $[1,2,3]$. The high-performance liquid chromatography enabled the identification of red pepper pigments and more than 40 carotenoid-type compounds were found, mainly esterified with fatty acids in a form of mono and diesters $[4,5]$.The diesters were more stable than monoesters and unesterified carotenoids during the post harvest operations and storage, therefore their larger amounts were found to be preferred even if the total carotenoid content was relatively low $[1,2,6]$. Furthermore, these studies showed that the colour stability of spice paprika during technological process and storage is affected by the level of antioxidants such as ascorbic acid and tocopherols formed the ripening of pods.

In the industrial and commercial practice, the quality of dried and milled paprika are evaluated on the basis of total extractable colour content which is measured by photometric method and expressed as ASTA value [7].Beside the extractable colour content the visual colour plays important role in the judgment of quality and colouring power, although the relation between them is not unequivocal [8].

The instrumental surface colour measurement enables to quantify the colour differences excluding the subjective verbal sensory descriptions. A number of authors publish their data in the CIELAB ( $\left.L^{*}, a^{*}, b^{*}\right)$ colour space system. The measure of a colour's lightness, $\mathrm{L}^{*}$, is correctly reported without further manipulation, however $\mathrm{a}^{*}$ and $\mathrm{b}^{*}$ are merely coordinates that indirectly reflect hue and chroma but are difficult to interpret separately [9]. More importantly, these coordinates are not independent variables [10]. 
Therefore, a more appropriate measure and interpretation of colour can be obtained by the calculation of hue angle $\left(\mathrm{h}^{\circ}{ }_{\mathrm{ab}}\right)$ and Chroma $\left(\mathrm{C}^{*}{ }_{\mathrm{ab}}\right)$ [9].

The CIELab colour space was found to be suitable for the evaluation of colour evolution which takes place during the paprika fruit ripening [11], while other study reported that the ASTA colour values were the best measure of spice paprika quality, compared with the lightness $\left(\mathrm{L}^{*}\right)$, hue angle $\left(\mathrm{h}_{\mathrm{ab}}^{\circ}\right)$ and $\mathrm{Chroma}\left(\mathrm{C}^{*}{ }_{\mathrm{ab}}\right)$ colour measurements [12].

At the end of 1990's and the beginning of 2000's the organic spice paprika cultivation started in Hungary. The crops and products from organic farming represent value-added products, contribute to the active health and environment protection, maintain the biodiversity, and have a good marketability. The organic crop production uses the diseases -resistant or tolerant spice paprika varieties which were originally bred for the conventional cultivation. Reports in the scientific literature have generally been limited to the conventionally cultivated spice paprika. The objective of this research work was to study and compare the colour evolution behaviour of spice paprika varieties as a function of organic and conventional crop production methods in the 2014 growing season.

\section{MATERIALS AND METHODS}

\subsection{Materials}

Four non-pungent red spice paprika (Capsicum annuum var. longum L.) varieties were used as experimental materials: Szegedi-20, Meteorit, Mihálytelki and Kármin.

The Szegedi-20 is a widely spread variety in the Szeged spice paprika production area, but sensitive to viruses. It has $100-120 \mathrm{~mm}$ long pendulous fruits, medium bush $(400-450 \mathrm{~mm})$, with thick foliage. The extractable colour content of pericarp is 240-330 ASTA after the over ripening of pods [13].

The Kármin has 100-120mm long pendulous fruits, medium bush (400-450 mm) with spreading loose foliage. The extractable colour content of over-ripened pericarp is 260-355 ASTA. [14].

The Meteorit has $100-140 \mathrm{~mm}$ long pendulous fruits, medium bush $(450-550 \mathrm{~mm})$ and high yield. It is susceptible neither to virus diseases nor to bacterial leaf spots. The pods mature uniformly with the extractable colour content of 240-300 ASTA. [15].

The Mihálytelki has 100-140mm long pendulous fruits, medium bush $(400-550 \mathrm{~mm})$ with dark green foliage. Its pods mature early with the extractable colour content of 210-240 ASTA. Due to the adaptability, this variety provides appropriate quantity and quality of fruits in unfavourable vintage. [16].

\subsection{Crop production}

The conventional and organic fields were located within the traditional Szegedi spice paprika production area (Hungary).

The samples of conventional crops were obtained from the production areas of Gorzsa Agricultural Co. (Hódmezővásárhely, Hungary). The main soil type is a meadow soil, that contains $2.6 \%$ of humus, and its $\mathrm{pH}$ value is 7.21 . The nutrient levels of soil were moderate in nitrogen $(14 \mathrm{mg} / \mathrm{kg}$ Nitrogen-nitrite + nitrate), good in phosphorus $\left(188 \mathrm{mg} / \mathrm{kg} \mathrm{P}_{2} \mathrm{O}_{5}\right)$, and moderate in potassium $\left(352 \mathrm{mg} / \mathrm{kg} \mathrm{K} \mathrm{K}_{2} \mathrm{O}\right)$. The fertilization plan based on the MÉM-NAK instructions [17], therefore $60 \mathrm{~kg} / \mathrm{ha}$ of phosphorus and $92 \mathrm{~kg} / \mathrm{ha}$ of potassium demands were established. The fertilisers $(100 \%$ of phosphorus and potassium demand) were added to the soil during the autumn tillage. The pre-crops were winter wheat; ploughing and disc tillage soil preparation was carried out in September-October 2013, then the soil was broken up and levelled with harrow in spring of 2014. The sowing was carried out in late March- early April, with a density of 4.52-5.45 kg/ha seeds and the row spacing was $0.45 \mathrm{~m}$. The cultivating and mechanical weeding were carried out in June and July. For the chemical plant protection treatments Teppeki insecticide $(0.14 \mathrm{~kg} / \mathrm{ha}$, two occasions in June and July), Pantera 40 EC herbicide (1.5 1/ha, in July) and Cuproxat FW fungicide (2 1/ha, at the beginning of August) were used. 
The organic paprika crops were obtained from the research production area (Balástya, Hungary) of the Rubin Spice Paprika Processing Szeged Ltd (Szeged, Hungary). The area is certified according to the organic farming legislations. The main soil type is sand, that contains $1.29 \%$ of humus, and its $\mathrm{pH}$ value is 7.5. The nutrient levels of soil is good in nitrogen $(0.20-0.25 \%)$, phosphorus $(0.20-0.25 \%)$, and in potassium (0.15-0.20\%). The pre-crop was rye, which was used as green-plant manure; therefore it was broken down then ploughing into the soil at the end of March 2014. The growing of paprika seedlings (in greenhouse, April-May) was followed by the transplanting (late May) with the help of hanging reel 4-line planter machine. The adjusted row distance was $0.60 \mathrm{~m}$ and within the rows, the spacing between the seedlings was $0.20 \mathrm{~m}$. The manual weed control was carried out at the end of June, July and August. For the chemical plant protection treatments Cuproxat FW fungicide (2.5 1/ha, in July and August) was used, which is allowed in organic farming.

The conventional and organic fields were equipped with irrigation system. However, because of the significant amount of precipitation, irrigation was not necessary. On the conventional fields $621.7 \mathrm{~mm}$ precipitation was registered from April to September, and $585.1 \mathrm{~mm}$ on the organic fields. The average precipitation of the last 5 years was $276.2 \mathrm{~mm}$.

\subsection{Sampling and sample preparation}

The pre-harvest inspections started in the middle of August, when the paprika pods were collected in green, break, and pale red colour stages from the organic and conventional fields as well. The samples of each varieties were picked within three designated rows separately (3 repetition), where the plants showed a uniform appearance. At the pre-harvest sample collection, the pods were sorted on the basis of green, break, and pale red ripening stages (Fig. 1).

The deep red (ripened) samples were collected at the beginning of September, a few days before the industrial harvest, from the previously designated rows. Deep red coloured pods were randomly separated and over-ripened under the outdoors conditions in rasher-bags for 2.5 weeks (Fig. 1).

For the investigations the healthy, well developed and steady coloured pods were used which showed the variety-specific characteristics.

At the sample collection, the spice paprika plantations were described with regard to their appearances, development and behaviour toward plant diseases.

For the extractable and surface colour measurements $1000 \mathrm{~g}$ of pods from each fresh and over-ripened sample were cut to $15-20 \mathrm{~mm}$ wide slices and dried gently in a forced air circulating oven at $50^{\circ} \mathrm{C}$ for 10 12 hours. The dried paprika samples were milled without the pedicels, till the entire amount of paprika powder fall through $500 \mu \mathrm{m}$ sieve (Fig. 2).

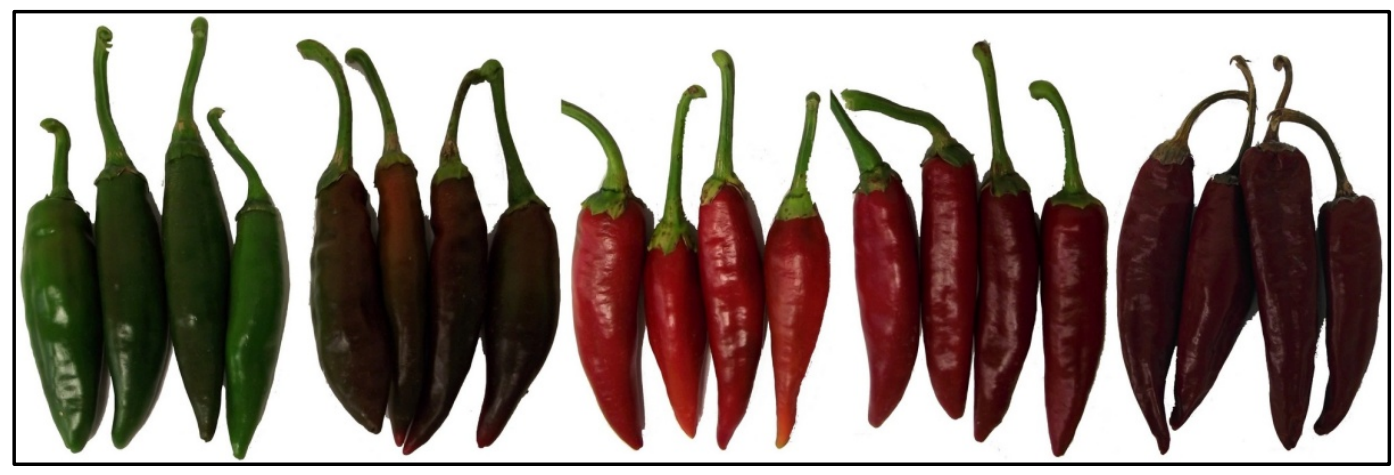

Figure 1. Samples of conventional Mihálytelki variety in green, break, pale red, deep red and over ripen stage 


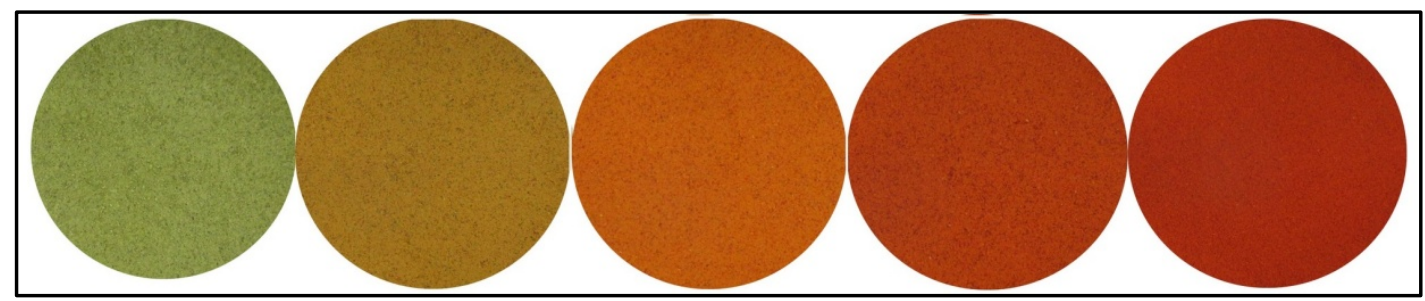

Figure 2. Dried and ground samples of conventional Mihálytelki variety in green, break, pale red, deep red and over ripen stage

\subsection{Determination of extractable colour content}

The extractable colour content (ASTA value) was determined according to the ASTA 20.1 method [7]. Paprika powder samples of $70-90 \mathrm{mg}$ were measured with $0.2 \mathrm{mg}$ accuracy, and transferred into $100 \mathrm{ml}$ volumetric flasks. The volume was then adjusted with acetone. After 4 hours a portion of the extract was transferred to the spectrophotometer cuvette and the absorbance was measured at $460 \mathrm{~nm}$ against an acetone blank. When the absorbance was over 0.7 , the sample solution was diluted. When the absorbance was under 0.3 , the weight of sample was increased. ASTA unit was calculated according to the formula:

$$
A S T A=\frac{\text { Absorbance } \cdot 16,4 \cdot \text { factor }}{\text { the weigh of sample }(\mathrm{g})}
$$

where the Factor $=0.315 /$ absorbance of the standard colour solution. Standard colour solution was prepared by dissolving $1.3500 \mathrm{~g}$ cobalt-chloride and $0.0125 \mathrm{~g}$ potassium-bi-chromate in $100 \mathrm{ml} 5 \%$ sulphuric acid.

\subsection{Surface colour measurements}

The surface colour measurements of milled paprika samples was carried out with the help of WF30 colorimeter (Shenzhen Wave Optoelectronics Technology Co. Ltd., D65 light source, 8mm, CIE standard observer $10^{\circ}$ ). The instrument works according to the CIELab colour space system, therefore the colour points are characterized by the $L^{*}$ (lightness) $a^{*}$ (redness) and $b^{*}$ (yellowness) coordinates. Each sample was measured three times, and between the readings the samples were mixed thoroughly. The hue angle $\left(\mathrm{h}_{\mathrm{ab}}^{\circ}\right)$ and chroma $\left(\mathrm{C}^{*}{ }_{\mathrm{ab}}\right)$ values were calculated from each measurement data:

$$
\begin{gathered}
h_{a b}^{\circ}=\operatorname{arctg} \frac{b^{*}}{\mathrm{a}^{*}} \\
C_{a b}^{*}=\left(\left(a^{*}\right)^{2}+\left(b^{*}\right)^{2}\right)^{\frac{1}{2}}
\end{gathered}
$$

The $L^{*} C^{*} h^{*}$ colour space uses cylindrical coordinates instead of rectangular coordinates $\left(L^{*}, a^{*}, b^{*}\right)$, where $\mathrm{C}^{*}{ }_{\mathrm{ab}}$ represents colour saturation or intensity from dull (low values) to vivid colour (high values), and $\mathrm{h}_{\text {ab }}^{\circ}$ can be defined as colour wheel with red-purple at an angle of 0 , yellow at 90, bluish green at 180, and blue at $270[9,18,19,20]$.

The colour difference $\left(\Delta \mathrm{E}^{*}{ }_{\mathrm{ab}}\right)$, lightness difference, $\left(\Delta \mathrm{L}^{*}\right)$, saturation difference $\left(\Delta \mathrm{C}^{*}{ }_{\mathrm{ab}}\right)$ and hue difference $\left(\Delta \mathrm{H}^{*}{ }_{\mathrm{ab}}\right)$ were calculated in order to compare the organic and conventional varieties in each ripening stages. The colour difference $\left(\Delta \mathrm{E}^{*}\right.$ ab $)$ express the spatial distance between two colour points in the colour space [20]:

$$
\Delta E_{a b}^{*}=\left[\left(L_{1}^{*}-L_{2}^{*}\right)^{2}+\left(a_{1}^{*}-a_{2}^{*}\right)^{2}+\left(b_{1}^{*}-b_{2}^{*}\right)^{2}\right]^{1 / 2}
$$

where, subscript 1 represents the sample (organic samples) and subscript 2 is the point of reference (conventional samples). 
Since the $\Delta \mathrm{E}^{*}{ }_{\mathrm{ab}}$ expresses the size of colour difference but not in what way the colours of samples are different, further calculations were used [21]:

$$
\begin{gathered}
\Delta L^{*}=L_{1}^{*}-L_{2}^{*} \\
\Delta C_{a b}^{*}=C_{a b 1}^{*}-C_{a b 2}^{*} \\
\Delta H_{a b}^{*}=\operatorname{sign}\left[a_{2}^{*} \cdot b_{1}^{*}-a_{1}^{*} \cdot b_{2}^{*}\right] \cdot\left[\left(\Delta E_{a b}^{*}\right)^{2}-\left(\Delta L^{*}\right)^{2}-\left(\Delta C^{*}\right)^{2}\right]^{1 / 2}
\end{gathered}
$$

\subsection{Data analysis}

Microsoft Excel (Microsoft Corporation, Redmond, WA) and Statistica 8 (Statsoft Inc., Tulsa, OK) software were used for the statistical analysis. The Shapiro-Wilk test confirmed the normal distribution of measurement data $(p>0.05)$, and the Levene's test showed the homogeneity of variance $(p>0.05)$. Therefore, factorial ANOVA (with production method and paprika varieties factors) followed by Post-hoc (Fisher's test) were applied for the detailed evaluation of experimental data in each ripening stages.

\section{RESULTS AND DISCUSSION}

The appearances of spice paprika plants on the conventional and organic fields were characterized in the followings:

The conventional and organic Meteorit showed a similar appearance, the bush tallness was 500-680 mm, there were no signs of disease, the plants and the pods were well-developed, powerful, the foliage was lush and hugged, the bond of yields were adequate.

In the case of conventional Kármin the bush tallness was 590-680 mm, there were no signs of disease. The plants and the pods were well-developed, and the foliage was robust and hugged. The organic Kármin paprika plantation was weaker, the signs of the disease were overall (bacterial blight, powdery mildew on the leaves), and the yields from the second flowering were not retained.

The conventional and organic Mihálytelki showed a similar appearance. The bush tallness was 400$600 \mathrm{~mm}$, the plants and the pods were well-developed, and the foliage was rarer as compared to the Meteorit and conventional Kármin, while the bond of yields were adequate.

The conventional Szegedi-20 had a 440-570 mm bush tallness, the signs of the disease were more frequent compared with other conventional varieties (bacterial blight, powdery mildew on the leaves), but the bond of yields were adequate. On the organic field the bush tallness was similar (460-560 mm), however the plantation was weakly developed with sparse foliage, signs of the disease overall (chlorosis, bacterial blight, powdery mildew on the leaves) and the yields were not retained from the second flowering.

The frequent disease could be attributed to that the precipitation were well above the average of last 5 year (Crop production point) this condition was suitable to demonstrate the behaviour of paprika varieties in extreme weather elements.

Based on the plantation appearance, the production of Szegedi-20 and Kármin varieties were prosperous in the conventional areas with the help of chemical plant protection treatments. The Meteorit paprika, due to its resistance to disease, and the Mihálytelki, due to its tolerance properties, were successfully cultivated on the conventional and organic fields as well.

Tab. 1 shows the extractable (ASTA) colour of spice paprika varieties from the conventional and organic crop production methods in the different ripening stages. The analysis of variance resulted that the production method and the varieties factors, as well as their interaction had a significant effect $(\mathrm{p}<0.05)$ on the variation of ASTA colour in the green, pale red and over-ripened stages. The effect of production method factor was not significant $(\mathrm{p}>0.05)$ in the break ripening stage. The interaction of production method and the varieties factors showed no significant effect $(p>0.05)$ on the ASTA values in the deep red ripening stage. 
Table 1. The extractable colour (ASTA) in the different ripening stages (average values of 3 repetitions)

\begin{tabular}{|l|c|c|c|c|c|c|c|c|}
\hline \multirow{2}{*}{$\begin{array}{c}\text { Ripening } \\
\text { stages }\end{array}$} & \multicolumn{2}{|c|}{ Szegedi-20 } & \multicolumn{2}{c|}{ Meteorit } & \multicolumn{2}{c|}{ Mihálytelki } & \multicolumn{2}{c|}{ Kármin } \\
\cline { 2 - 9 } & conv. & organic & conv. & organic & conv. & organic & conv. & organic \\
\hline Green & $10.5 \mathrm{~b}$ & $13.2 \mathrm{~b}$ & $7.6 \mathrm{c}$ & $11.0 \mathrm{~b}$ & $11.3 \mathrm{~b}$ & $22.8 \mathrm{a}$ & $10.5 \mathrm{~b}$ & $14.6 \mathrm{~b}$ \\
\hline Break & $55.7 \mathrm{~b}$ & $51.4 \mathrm{~b}$ & $38.2 \mathrm{~d}$ & $32.2 \mathrm{e}$ & $53.6 \mathrm{~b}$ & $68.1 \mathrm{a}$ & $54.1 \mathrm{~b}$ & $48.0 \mathrm{c}$ \\
\hline Pale red & $81.9 \mathrm{~b}$ & $108.9 \mathrm{a}$ & $79.6 \mathrm{~b}$ & $104.5 \mathrm{a}$ & $104.9 \mathrm{a}$ & $81.0 \mathrm{~b}$ & $78.7 \mathrm{c}$ & $84.9 \mathrm{~b}$ \\
\hline Deep red & $187.8 \mathrm{a}$ & $169.6 \mathrm{~b}$ & $138.7 \mathrm{~d}$ & $121.4 \mathrm{e}$ & $183.7 \mathrm{a}$ & $161.6 \mathrm{c}$ & $175.0 \mathrm{~b}$ & $159.0 \mathrm{c}$ \\
\hline Over ripened & $229.3 \mathrm{~b}$ & $210.5 \mathrm{c}$ & $169.9 \mathrm{f}$ & $160.8 \mathrm{~g}$ & $227.5 \mathrm{~b}$ & $184.7 \mathrm{e}$ & $264.8 \mathrm{a}$ & $201.9 \mathrm{~d}$ \\
\hline
\end{tabular}

${ }^{1}$ The same letters indicate no significant difference $(\mathrm{p}>0.05)$ between the samples in the same ripening stage

The climacteric ripeness starts in green fruits and proceeds through colour break stages toward the biological ripeness [1]. The ASTA values of green paprika pods (7.62-22.7 ASTA) indicated that the carotenoid biosynthesis was in early stage. The organic paprika samples had slightly higher initial extractable colour content than their conventional counterparts, due to the advantageous effect of the previous seedling and the sparser plantation density as it was described in the "Crop production" point.

During the course of ripening the extractable colour contents were increasing considerably, as a result of the accumulation of brownish-red pigments. The most remarkable changes were found between the pale red and deep red maturity stages. Ref. [1] reported that dramatic change took place in the content of monoand diesters in the red ripe fruits and an overall 24-fold carotenoid content increase was recorded during the ripening. The organic paprika varieties gradually lost their initial ASTA colour gain toward their conventional counterparts particularly after the pale red stage. This tendency was attributed to the favourable soil characteristics of conventional field, the nutrient supply and chemical plant protection that were specifically designed in order to fulfil the physiological demand of spice paprika. The conventional Szegedi-20 and Kármin showed the highest colour value increase (105 and 92.6 ASTA respectively) followed by the conventional and organic Mihálytelki (78.7- 80.6 ASTA) and the organic Kármin (74.1 ASTA). The least colour accumulation was observed in the organic Szegedi-20 and Meteorit variety (60.659.0 ASTA). The great extractable colour difference between the pale and deep red pods indicated that the harvest has a crucial effect on the quality and commercial value of final spice paprika products. Therefore, traditionally the harvest is carried out in different picking periods adjusted to the different time of ripening [22].

However, the maturity stage at harvest does not mean the technological ripeness of the crop; therefore the spice paprika needs to over-ripen [1]. The carotenoid biosynthesis continues to produce more red pigments in a form of stable fatty acid mono- and diesters [1,6].The most intensive over-ripening process was observed in the conventional Kármin variety, which showed 89.8 ASTA units increase, although its colour content was lower at the harvest period, compared with the Szegedi-20 and the Mihálytelki samples. The conventional Szegedi-20 and Mihálytelki, the organic Szegedi-20, Meteorit and Kármin showed similar colour accumulation (40.9- 43.9ASTA) during the 2.5 weeks over-ripening. The smallest increase (31.123.0 ASTA) was established for the conventional Meteorit and organic Mihálytelki.

As the different varieties were compared, it was clear that the organically cultivated varieties obtained significantly lower ASTA colour levels than the conventional ones. Although the Meteorit had the lowest colour content, it is a preferred variety in the spice paprika producer circles because of its resistance, high yield and uniformity at mature stage.

Table 2 shows the instrumental surface colour characteristics of spice paprika varieties from the conventional and organic fields in the different ripening stages. The colour characteristics were measured from the dried and milled $(<500 \mu \mathrm{m})$ samples of pods, because this form enabled the evaluation with regard to the paprika powder quality and decreased the errors derived from the unevenness surface of pods. 
Table 2. The instrumental colour characteristics of conventional and organic samples at the different ripening stages (averages values of 3 repetitions)

\begin{tabular}{|c|c|c|c|c|c|c|c|c|c|}
\hline & \multirow{2}{*}{$\begin{array}{c}\text { Ripening } \\
\text { stages }\end{array}$} & \multicolumn{2}{|c|}{ Szegedi-20 } & \multicolumn{2}{|c|}{ Meteorit } & \multicolumn{2}{|c|}{ Mihálytelki } & \multicolumn{2}{|c|}{ Kármin } \\
\hline & & conv. & organic & conv. & organic & conv. & organic & conv. & organic \\
\hline \multirow[t]{5}{*}{$\mathbf{L}^{*}$} & Green & $61.12 c^{1}$ & $60.47 \mathrm{c}$ & $61.77 \mathrm{~b}$ & $62.17 \mathrm{~b}$ & $64.77 \mathrm{a}$ & $60.54 \mathrm{c}$ & $60.28 \mathrm{c}$ & $59.23 \mathrm{~d}$ \\
\hline & Break & $53.59 \mathrm{c}$ & $54.85 \mathrm{~b}$ & $54.27 \mathrm{~b}$ & $56.13 \mathrm{a}$ & $51.59 \mathrm{e}$ & $53.53 \mathrm{c}$ & $52.38 \mathrm{~d}$ & $52.88 \mathrm{~d}$ \\
\hline & Pale red & $53.60 \mathrm{a}$ & $51.39 \mathrm{~b}$ & $51.55 \mathrm{~b}$ & $51.71 \mathrm{~b}$ & $51.07 \mathrm{c}$ & $51.99 \mathrm{~b}$ & $51.27 \mathrm{c}$ & $52.28 \mathrm{~b}$ \\
\hline & Deep red & $49.25 \mathrm{a}$ & $49.44 \mathrm{a}$ & $49.76 \mathrm{a}$ & $49.60 \mathrm{a}$ & $48.25 \mathrm{~b}$ & $48.74 \mathrm{~b}$ & $47.12 \mathrm{~d}$ & $49.43 \mathrm{a}$ \\
\hline & Over ripe & $46.53 \mathrm{c}$ & $48.87 \mathrm{a}$ & $47.83 \mathrm{~b}$ & $47.78 \mathrm{~b}$ & $47.69 \mathrm{~b}$ & $48.62 \mathrm{a}$ & $46.74 \mathrm{c}$ & $47.78 \mathrm{~b}$ \\
\hline \multirow[t]{5}{*}{$\mathrm{C}_{\mathrm{ab}}$} & Green & $20.52 \mathrm{e}$ & $22.60 \mathrm{c}$ & $22.55 \mathrm{c}$ & $21.65 \mathrm{~d}$ & $23.61 \mathrm{~b}$ & $28.06 \mathrm{a}$ & $20.29 \mathrm{e}$ & $21.51 \mathrm{~d}$ \\
\hline & Break & $25.95 \mathrm{e}$ & $25.91 \mathrm{e}$ & $27.82 \mathrm{c}$ & $24.80 \mathrm{f}$ & $29.03 \mathrm{~b}$ & $34.02 \mathrm{a}$ & $27.74 \mathrm{c}$ & $27.00 \mathrm{~d}$ \\
\hline & Pale red & $31.19 \mathrm{c}$ & $28.74 \mathrm{~d}$ & $32.89 \mathrm{~b}$ & $33.60 \mathrm{a}$ & $32.81 \mathrm{~b}$ & $37.38 \mathrm{a}$ & $33.39 \mathrm{a}$ & $26.87 \mathrm{e}$ \\
\hline & Deep red & $29.21 \mathrm{~b}$ & $27.81 \mathrm{c}$ & $31.67 \mathrm{a}$ & $32.53 \mathrm{a}$ & $30.62 \mathrm{a}$ & $31.40 \mathrm{a}$ & $30.47 \mathrm{~b}$ & $27.67 \mathrm{c}$ \\
\hline & Over riper & $28.25 \mathrm{c}$ & $31.54 \mathrm{a}$ & $30.84 \mathrm{~b}$ & $31.36 \mathrm{a}$ & $30.16 \mathrm{~b}$ & $31.48 \mathrm{a}$ & $31.61 \mathrm{a}$ & $29.81 \mathrm{~b}$ \\
\hline \multirow[t]{5}{*}{$\mathbf{h}^{\circ}{ }_{\mathrm{ab}}$} & Green & $84.89 \mathrm{c}$ & $82.36 \mathrm{~d}$ & $87.85 \mathrm{a}$ & $80.54 \mathrm{e}$ & $88.24 \mathrm{a}$ & $60.38 \mathrm{f}$ & $86.40 \mathrm{~b}$ & $78.28 \mathrm{~g}$ \\
\hline & Break & $56.29 \mathrm{c}$ & $60.35 \mathrm{~b}$ & $54.47 \mathrm{~d}$ & $62.50 \mathrm{a}$ & $47.42 \mathrm{~g}$ & $49.22 \mathrm{f}$ & $52.74 \mathrm{e}$ & $52.30 \mathrm{e}$ \\
\hline & Pale red & $44.88 \mathrm{a}$ & $44.92 \mathrm{a}$ & $40.88 \mathrm{c}$ & $44.30 \mathrm{a}$ & $39.58 \mathrm{~d}$ & $42.97 \mathrm{~b}$ & $45.58 \mathrm{a}$ & $45.19 \mathrm{a}$ \\
\hline & Deep red & $36.96 \mathrm{a}$ & $36.66 \mathrm{a}$ & $37.47 \mathrm{a}$ & $35.03 \mathrm{~b}$ & $33.78 \mathrm{~b}$ & $33.96 \mathrm{~b}$ & $31.54 \mathrm{c}$ & $36.24 \mathrm{a}$ \\
\hline & Over ripen & $28.16 \mathrm{~d}$ & $34.65 \mathrm{a}$ & $30.65 \mathrm{~b}$ & $29.47 \mathrm{c}$ & $31.19 \mathrm{~b}$ & $31.58 \mathrm{~b}$ & $28.08 \mathrm{~d}$ & $30.12 \mathrm{c}$ \\
\hline
\end{tabular}

The same letters indicate no significant difference $(\mathrm{p}>0.05)$ between the samples in the same ripening stage

The analysis of variance revealed that the production method, the varietal factors, and their interaction had a significant effect $(p<0.05)$ on the variation of colour parameters in the majority of ripening stages. The production method factor had no significant effect on the $L^{*}$ coordinates $(p>0.05)$ in the pale red stage, and on the $\mathrm{h}_{\mathrm{ab}}^{\circ}$ values $(\mathrm{p}>0.05)$ in the red (harvest) stage. The post hoc test indicated that the tendencies of similarities and dissimilarities between the organic and conventional varieties were not consistent in the different ripening stages.

As the ripening forwarded, the $\mathrm{L}^{*}$ values decreased, indicating that the paprika samples obtained darker colour. The most remarkable changes were found between the green and break ripening stages, when the lightness values decreased with 5.62-13.8 units. In the next maturation phases the magnitude of decreasing became moderate and varied between 0.52 and 4.32 units. The dissimilarities decreased between the $L^{*}$ values of samples. When the pods reached the harvest-maturity (steady deep red) stage, the conventional Kármin showed the lowest $\mathrm{L}^{*}$ level, this was followed by the conventional and organic Mihálytelki. There were no significant difference $(\mathrm{p}>0.05)$ between conventional and organic Szegedi-20, Meteorit and organic Kármin samples.

The Chroma $\left(\mathrm{C}^{*}\right.$ ab $)$ represents the colour saturation [18], therefore the increasing level indicated that the colour of pods became vivid during the ripening. Similarly to the $\mathrm{L}^{*}$ values, the most remarkable $\mathrm{C}^{*}{ }_{\mathrm{ab}}$ changes were observed between the green and break stage. The conventional samples showed better $\mathrm{C}^{*}{ }_{\mathrm{ab}}$ increase (7.45-5.27 units) than their organic alternatives (3.15-5.96). The level of $\mathrm{C}^{*}{ }_{\mathrm{ab}}$ tended to slightly decrease with the advanced ripening, and the dissimilarities decreased between the samples. At the harvest (deep red stage) the conventional and organic Meteorit and Mihálytelki samples showed the most vivid colour, followed by the conventional Szegedi-20 and Kármin, while the organic Szegedi-20 and Kármin were the least saturated.

The hue angle is defined as a colour wheel, with red purple at the angle of $0^{\circ}$ and yellow at $90^{\circ}$ [23]. In the green pods the $\mathrm{h}_{\mathrm{ab}}^{\circ}$ values were near to $90^{\circ}$ indicating the low level of red pigments. The dramatic change took place between the green and break colour stages, when 28.60-40.82 units $\mathrm{h}_{\mathrm{ab}}^{\circ}$ decrease was found in the conventional pods, while the organic ones showed lower (11.16-25.98) changes. The $\mathrm{h}_{\mathrm{ab}}^{\circ}$ decrease became moderate during the further ripening, but showed higher changes than the $\mathrm{L}^{*}$ and $\mathrm{C}^{*}$ ab after the break colour stage. In harvest-maturity (deep red) stage the reddest surface colour was found in the 
conventional Kármin, followed by the organic Meteorit and conventional Mihálytelki, while the other samples showed lower $\mathrm{h}^{\circ}$ ab without significant differences.

As a result of 2.5 weeks over-ripening, the $\mathrm{h}^{\circ}$ ab values showed more remarkable changes than the $\mathrm{L}^{*}$ and $\mathrm{C}^{*} \mathrm{ab}$, indicating the accumulation of red carotenoids.

Table 3. The calculated colour difference parameters between the conventional and organic samples in the different ripening stages (averages values of 3 repetitions)

\begin{tabular}{|l|l|c|c|c|c|}
\hline \multicolumn{1}{|c|}{ Samples } & Ripening stage & $\mathbf{\Delta \mathbf { E } ^ { * }}{ }_{\mathbf{a b}}$ & $\mathbf{\Delta \mathbf { L } ^ { * }}$ & $\boldsymbol{\Delta} \mathbf{C}^{*}{ }_{\mathbf{a b}}$ & $\mathbf{\Delta} \mathbf{H}^{*}{ }_{\mathbf{a b}}$ \\
\hline Szegedi-20 Conv-Org. & Green & 2.424 & -0.65 & 2.08 & -0.95 \\
\cline { 2 - 6 } & Break & 2.330 & 1.26 & -0.04 & 1.84 \\
\cline { 2 - 6 } & Pale red & 3.366 & -2.21 & -2.45 & 0.57 \\
\cline { 2 - 6 } & Deep red & 1.467 & 0.19 & -1.40 & -0.16 \\
\cline { 2 - 6 } & Over ripened & 5.281 & 2.34 & 3.29 & 3.38 \\
\hline Meteorit Conv-Org. & Green & 3.164 & 0.40 & -0.89 & -2.82 \\
\cline { 2 - 6 } & Break & 5.192 & 1.86 & -3.03 & 3.68 \\
\cline { 2 - 6 } & Pale red & 2.341 & 0.16 & 0.70 & 1.99 \\
\cline { 2 - 6 } & Deep red & 1.680 & -0.16 & 0.86 & -1.36 \\
\cline { 2 - 6 } & Over ripened & 1.033 & -0.05 & 0.52 & -0.64 \\
\hline Mihálytelki Conv-Org. & Green & 13.836 & -4.23 & 4.45 & -12.39 \\
\cline { 2 - 6 } & Break & 8.640 & 1.94 & 8.35 & 1.03 \\
\cline { 2 - 6 } & Pale red & 2.612 & 0.93 & 1.21 & 1.97 \\
\cline { 2 - 6 } & Deep red & 1.339 & 0.69 & 0.77 & 0.49 \\
\cline { 2 - 6 } & Over ripened & 1.710 & 0.93 & 1.32 & 0.49 \\
\hline Kármin Conv-Org. & Green & 3.429 & -1.05 & 1.22 & -2.96 \\
\cline { 2 - 6 } & Break & 1.145 & 0.50 & -0.74 & -0.46 \\
\cline { 2 - 6 } & Pale red & 6.607 & 1.01 & -6.52 & -0.20 \\
\cline { 2 - 6 } & Deep red & 4.414 & 2.31 & -2.80 & 2.38 \\
\cline { 2 - 6 } & Over ripened & 2.367 & 1.04 & -1.80 & 1.09 \\
\hline
\end{tabular}

Tab. 3 contains the calculated colour difference parameters of conventional and organic paprika sample in each ripening stages. Previous study [23] demonstrated that if the $\Delta \mathrm{E}^{*}{ }_{\mathrm{ab}}>1.5$, then the colour difference between two paprika powders can be visually distinguished. The calculated values showed significant and perceptible visual colour differences between the organic and conventional paprika samples in the majority of ripening stages. Similarities were found merely between the over-ripened conventional and organic Meteorit, between the deep red conventional and organic Mihálytelki, and between the break conventional and organic Kármin. The lightness difference $\left(\Delta \mathrm{L}^{*}\right)$, saturation difference $\left(\Delta \mathrm{C}^{*}{ }_{\mathrm{ab}}\right)$ and hue difference $\left(\Delta \mathrm{H}^{*}{ }_{\mathrm{ab}}\right)$ showed the way with which the colours of samples are different. The positive $\Delta \mathrm{L}^{*}$ values indicated that the paprika samples from the organic farming generally were lighter than the conventional ones. The positive $\Delta \mathrm{C}^{*}$ ab showed that the organic Szegedi-20 and Kármin were less saturated than their conventional counterparts. However the organic Meteorit and Kármin tented to showed more vivid colour than their conventional alternatives. The positive $\Delta \mathrm{H}^{*}$ ab values showed that the colour of organic paprika crops were closer to $+b^{*}$ axis, revealing that they were more yellow than the conventional ones.

When the samples represented graphically as the function of $\mathrm{L}^{*}, \mathrm{~h}_{\mathrm{ab}}^{\circ}$ and $\mathrm{C}^{*}{ }_{\mathrm{ab}}$ values (Fig. 3), almost complete overlapping was found between the harvest-maturity (deep red) and over-ripened stages. These tendencies indicated that, although the extractable colour content increment was significant between mature red and over-ripe products, the $\mathrm{L}^{*}, \mathrm{~h}^{\circ}{ }_{\mathrm{ab}}$ and $\mathrm{C}^{*}{ }_{\mathrm{ab}}$ values were not sufficient to distinguishing the ripening stages. Fig. 4 illustrates that the $\mathrm{L}^{*}, \mathrm{~h}^{\circ}{ }_{\mathrm{ab}}$ and ASTA colour values were the best parameters to distinguish the ripening stages and the colour characteristics of the samples. The harvest-maturity (deep 
red) stage of dried and milled pods were characterized with the $\mathrm{L}^{*}$ values around 50 units and the $\mathrm{h}_{\mathrm{ab}}$ under 40 units.

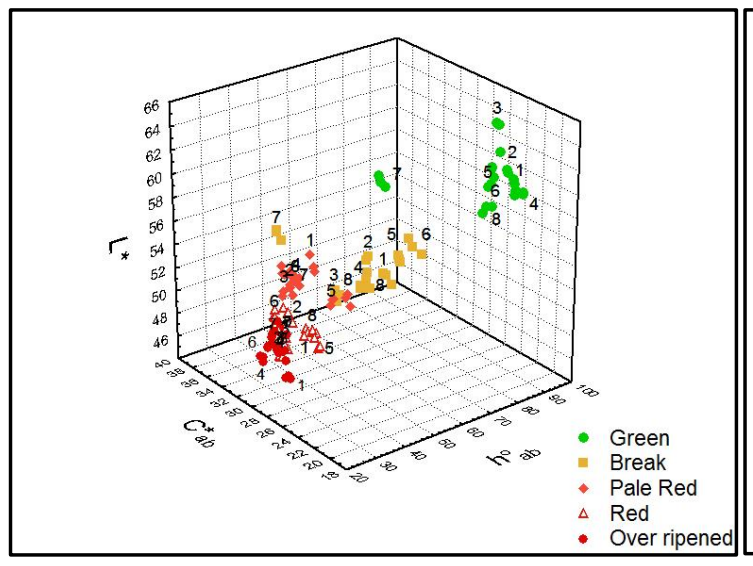

7igure 3. The positions of the samples as the function of $L *, h_{a b}^{\circ}$ and chroma $C^{*}{ }_{a b}$

Sample marking: 1. Conventional Szegedi-20, 2. Conventional Meteorit, 3. Conventional Mihálytelki, 4. Conventional Kármin, 5. Organic Szegedi-20, 6. Organic Meteorit, 7. Organic Mihálytelki, 8. Organic Kármin

\section{CONCLUSIONS}

Based on the appearance of plantations, it was concluded that the cultivation of Meteorit and Mihálytelki varieties were effective and profitable on the certified organic field according to the organic crop production principles. This was attributed to the disease resistant and tolerance properties of these varieties. All of the studied varieties were successfully cultivated on the conventional fields due to the nutrient supply and chemical plant protection that were specifically designed to fulfil the physiological demand of spice paprika.

The organic paprika samples showed lower red pigment accumulation (ASTA values) than the conventional ones. The weaker colour evolution power was confirmed by the instrumental surface colour measurement as well, since the paprika varieties from the organic fields were lighter, more yellow, and in the case of two varieties less saturated, than their conventional counterparts.

The result suggested that further experiments are necessary to establish the most suitable and optimized nutrient supply for the organic cultivation of spice paprika, which meet the requirement of the organic farming principles.

\section{ACKNOWLEGEMENT}

This work was supported by the Rubin Spice Paprika Processing Szeged Ltd., the Gorzsa Agricultural PLC. (Hungary, traditional spice paprika production area of Szeged), the Research Centre of Excellence9878/2015/FEKUT, and KTIA_AIK_12-1-2012-0012" projects. We thank Csaba N. Miklós (BSc.) for the organic paprika crop production. We also thank Laszlo Kruppai (BSc.) for the assistance in the laboratory works.

\section{REFERENCES}

[1] F. Márkus, H. G. Daood, J. Kapitany, and P. A. Biacs, Change in the carotenoid and antioxidant content of spice red pepper (paprika) as a function of ripening and some technological factors, Journal of Agricultural and Food Chemistry, 47 (1999), pp. 100-107. 
[2] H. G. Daood, J. Kapitany, P. A. Biacs and K. Albrecht, Drying temperature, endogenous antioxidants and capsaicinoids affect carotenoid stability in paprika (red pepper spice), Journal of the Science of Food and Agriculture, 86 (2006), pp. 2450-2457.

[3] U. Schweiggert, K. Kurz, A. Schieber, and R. Carle, Effects of processing and storage on the stability of free and esterified carotenoids of red peppers (Capsicum annuum L.) and hot chilli peppers (Capsicum frutescens L.), European Food Research and Technology, 225 (2006), pp. 261-270.

[4] K. Gasztonyi, and R. Lásztity, Élelmiszer-kémia 1, Mezőgazda Kiadó, Budapest, 1992

[5] M. Jaren-Galan, and M. I. Miguez-Mosquera, Quantitative and qualitative changes associated with heat treatments in the carotenoid content of paprika, Journal of Agricultural and Food Chemistry 47 (10) (1999), pp. 4379-4383.

[6] M. I. Miguez-Mosquera, D. Honero-Méndez,Changes in carotenoid esterification during the fruit ripening of Capsicum annuum cv Bola, Journal of Agricultural and Food Chemistry, 42 (1994), pp. 640-644.

[7] American Spice Trade Association (ASTA), 1997. 20.1. Extractable Colour in Capsicums and Their Oleoresins, 4th edition, Official Analytical Methods of the American Spice Trade Association, (1997) $89 \mathrm{pp}$.

[8] Zs. H. Horvath, and M. Halasz-Fekete, Instrumental colour measurement of paprika grits. Annals of the Faculty of Engineering Hunedora (2005), pp. 101-107.

[9] G. R. McGuire, Reporting of Objective Color Measurements, Hortscience, 27(12) (1992), pp. 12541255.

[10]F. J. Francis, Color quality evaluation of horticultural crops, HortScience 15 (1980), pp. 58-59.

[11]R. Gomez-Ladrón de Guevara, E. J. Pardo-González, Evolution of colour during the ripening of selected varieties of paprika pepper (Capicum annuum L.), Journal of Agricultural and Food Chemistry 44 (1996), pp. 2049-2052.

[12]M. Krajayklang, A. Klieber, and R. P. Dry, Colour at harvest and post harvest behavior influence paprika and chili spice quality, Postharvest Biology and Technology 20 (2000), pp. 269-278.

[13]K.Kapeller, A füszerpaprika, in: S. Balázs (ed.), Zöldségtermesztők kézikönyve. Mezőgazda Kiadó, Budapest, Hungary, 1994, pp. 256-277.

[14]Füszerpaprika Kutató Fejlesztő Kft, Füszerpaprika Fajtaajánlat. Kalocsa, Hungary, 2004, pp. 8

[15] Szegedi Paprika ZRt., Saját nemesítésü füszerpaprika fajták. Available at: http://szegedipaprika.hu/fuszerpaprika-tortenete/szegedi-paprika-zrt-sajat-nemesitesu-fuszerpaprika-fajtai/ 2015

[16]J. Kapitány, and F. Márkus, A fúszerpaprika termesztése és feldolgozása. Szaktudás ház kiadó ZRt, Budapest, Hungary, 2001, 46 pp.

[17] Mezőgazdasági és Élelmezésügyi Minisztérium Növényvédelmi és Agrokémiai Főosztály (MÉM NAK), Mütrágyázási irányelvek és üzemi számítási módszer. Budapest, Hungary, 1979

[18]R. S. Hunter, Photoelectric tristimulus colorimetry with three filters, Government printing office, Washington, D.C., USA, reprinted in Journal of the Optical Society of America 32 (1942), pp. 509538.

[19]A. C. Little, Off on a tangent. Journal of Food Science, 40 (1975), pp. 410-411.

[20]Konica Minolta Sensing INC, Precise colour communication, 2007, pp. 20-22

[21] Gy. Lukács, Színmérés. Müszaki Kiadó, Budapest, Hungary, 1982, pp. 341

[22Szegedi füszerpaprika őrlemény vagy Szegedi paprika termékleírás, AGRI/04-64775-00-01-HU(2008) http://elelmiszerlanc.kormany.hu/download/5/5f/20000/Szegedi_paprika_termekleiras_2008_12_15.pdf.

[23]Zs. H. Horváth, Procedure for setting the colour characteristics of paprika grits mixtures, Acta Alimentaria 36 (2007), pp. 75-88. 